\title{
Reglero de LA Fuente, Carlos Manuel (coord.), Poderes, espacios y escrituras. Los reinos de Castilla y León (siglos X-XV), Madrid, Sílex, 2018, 265 pp., ISBN: 978-84-7737-987-4.
}

DOI: https://doi.org/10.24197/em.20.2019.448-451

La publicación de obras colectivas viene siendo una de las maneras como se expresan los resultado obtenidos por los equipos que desarrollan proyectos de investigación. Es una forma de producción científica que ha alcanzado bastante consenso en el mundo académico, bien en forma de libros, bien de dosieres en revistas especializadas. Y eso es básicamente lo que se contiene en este libro: algunos de los resultados de un proyecto de investigación del Plan Nacional, dirigido por Carlos Reglero, coordinador de este libro. El hecho de estar avalado por un proyecto del Plan Nacional es ya un indicador de que el libro parte de unos estándares de calidad medios o altos. Por supuesto, ese presupuesto no se cumple en todos los casos, pero sí, y sobradamente, en éste. Claro que tratándose de una obra colectiva cada lector encontrará más interés en unos u otros trabajos. Hay una temática amplia y un marco cronológico extenso. Pero, en conjunto, se trata de una obra que, a mi juicio es muy relevante y expresa la madurez del equipo de investigación.

La relación entre los poderes y los espacios constituye una línea de investigación que ha dado frutos muy fecundos en las últimas décadas. No me parece necesario desarrollar más ese argumento, baste recordar algunos nombres como C. Estepa o J. A. García de Cortázar, o el propio coordinador de este libro (uno de cuyos primeros libros ya llevaba esas palabras en su título), o P. Martínez Sopena, otro de los autores de este libro. La relación entre los poderes y las escrituras, sin que sea nueva en la historiografía, sí ha alcanzado un desarrollo notable en los últimos años, quizás por influencia del interés por la historia cultural, uno de los campos preferidos en la actualidad. Una de las formas como se ha plasmado ha sido la renovación y puesta al día de los estudios de los cartularios. De manera que las nociones "poderes, espacios y escrituras" conforman una muy buena carta de presentación historiográfica.

Resumiré los aspectos más relevantes de las contribuciones, aunque vaya por delante mi recomendación de la lectura de todo el volumen puesto que, a mi juicio, se trata de un muy buen libro. Según señala el propio coodinador en la introducción, los ocho trabajos que se incluyen en él pueden dividirse en dos grupos: los cinco primeros ponen su acento en la relación entre los poderes y los espacios y los tres últimos incluyen además a las escrituras.

Inés Calderón, autora de la primera contribución, se ha ganado en los últimos años una posición destacada en los estudios sobre la nobleza plenomedieval. Su 
trabajo sobre la movilidad, sobre todo geográfica, de la nobleza tiene una gran originalidad por la combinación de fuentes hagiográficas, literarias y genealógicas. Merece la pena destacar que una de sus conclusiones es que la movilidad entre los reinos fue una de las grandes fuentes de poder para ciertos sectores de la nobleza (p. 53).

El coordinador del libro, Carlos Reglero, también aporta su propia contribución en la que estudia los conflictos entre el monasterio de Sahagún y el concejo de la villa; en realidad entre el monasterio y el sector que podríamos considerar la oligarquía urbana de Sahagún encabezada por Ruy Fernández. El conflicto quedó recogido en el texto que es conocido como Segunda Crónica Anónima de Sahagún. Reglero realiza un análisis también creo que muy original. No relata y glosa el texto de la Crónica, exponiendo el devenir de los acontecimientos de manera cronológica; sino que analiza el desenvolvimiento del conflicto en cuatro ámbitos espaciales (y políticos): la villa de Sahagún, la corte regia, el monasterio y la comarca. También me parecen muy destacables sus aportaciones relacionando las disputas con la proyección de los bandos y facciones de las principales familias de Sahagún y rechazando un relato lineal de la lucha de los burgueses por sus libertades (p. 83).

En el siguiente capítulo, Álvaro Sanz Martín analiza la política concejil de Alfonso X, su programa de reorganización de los concejos basada en el Fuero Real. Examina los que considera fueron los tres ejes que articularon esa política: las convocatorias de Cortes y las hermandades, la política foral y el clientelismo regio hacia sectores de las élites urbanas. Destaca finalmente que, a pesar de las pretensiones uniformizadoras del rey, se desarrollaron diferencias regionales entre Castilla, León y la Extremadura histórica (p. 110).

A continuación Pascual Martínez Sopena estudia el convulso período entre 1280-1350 centrándose en la comarca de Tierra de Campos. Tras una interesante introducción fundamentalmente historiográfica, desenvuelve su análisis en torno a dos grandes aspectos. Por un lado, cómo repercutieron y de qué manera se desarrollaron en la Tierra de Campos los conflictos y guerras que tuvieron lugar en esos años. En ese apartado el autor incluye también una muy interesante revisión de la redistribución de rentas regias que recogen los textos conservados de las rentas de Sancho IV. En la segunda parte de su contribución, Martínez Sopena estudia las que denomina "vertientes de la crisis"; esto es, el desenvolvimiento de la crisis en Tierra de Campos centrándose en determinadas vertientes, como son las condiciones sociales y el estatuto de la tierra en ese período entre 1280 y 1350 . Incluye un sugerente apartado sobre la inestabilidad de los señoríos en la primera mitad del siglo XIV por los vaivenes políticos y también por la evolución de las formas señoriales, sobre todo la trasformación de behetrías en solariegos.

Por su parte, Juan Prieto analiza los traslados de monasterios realizados por los poderosos en la Baja Edad Media: los traslados realizados por la familia real, los realizados por la nobleza, los promovidos por las oligarquías urbanas y los 
promovidos por las jerarquías eclesiásticas. El trabajo se desarrolla mediante el estudio de casos y el autor enfatiza que los traslados de monasterios son otro de los campos donde se desenvuelven las rivalidades y las alianzas de los grupos de poder (p. 178).

Las tres últimas contribuciones que cierran el libro incorporan la atención a las escrituras de forma más expresa. Miguel Calleja analiza los preámbulos de la cancillería de Alfonso VII. El estudio de los preámbulos o arengas de los documentos está renovándose en los últimos años y su mayor interés radica no tanto en el enfoque estríctamente diplomático (algo, por lo demás, necesario) como en la capacidad de esos trabajos para obtener conclusiones sobre la representación política, la visión de sí mismos o la propaganda que los poderosos exponían mediante ellos. Ese es también el objetivo de este trabajo que se centra sobre todo en los preámbulos diplomáticos; esto es, aquellos que destacan el valor de la escritura y los textos escritos. El autor examina la evolución de la cancillería del emperador, lo que le permite ver cómo se va acentuando el interés por la escritura como garantía de legalidad. Por otra parte, su trabajo le permite también matizar la idea de pobreza cultural de León y Castilla a mediados del siglo XII (p. 202).

Sumando los recursos de la Paleografía, la Diplomática y la Historia Social Alberto Navarro estudia cómo surge en la catedral de León la realización de obituarios, fuentes bien importantes y a las que no siempre se ha prestado la debida atención. A partir de la edición de los textos realizada en su día por M. Herrero Jiménez, el autor revisa los orígenes de estos textos a partir del análisis del llamado códice 30 realizado a finales del siglo XII que, a su vez, tomó como fuente otro anterior de finales del siglo XI que no se ha conservado. Dejando de lado la menos interesante cuestión sobre si los textos son necrologios u obituarios, el autor concluye que se puede poner en relación la elaboración del necrologio estudiado con la defensa de los intereses patrimoniales del cabildo (tras la asignación de bienes a la mesa capitular realizada por el obispo Diego en 1120). Otros textos, como el cartulario conocido como Libro de las Estampas, se realizaron por los mismos años para defender, en ese caso, las propiedades del obispo (p. 229).

Y la última contribución de este libro corresponde a Soledad Morandeira de Paz que estudia la cartografía medieval en la configuración de identidades, territorios y memoria. Su aportación se desarrolla en tres partes. Una primera, de introducción, en la que la autora pone al día las interpretaciones más recientes sobre cartografía medieval. Es posible que los lectores especializados la encuentren superflua, pero los no especializados (como es mi caso) la encontrarán sugerente, breve y bien escrita. A continuación la autora se centra en los mapas que se contienen en los Beatos, mapas que se incluyeron en un buen número de esos códices (14 de los conservados) para mostrar los lugares de evangelización de los apóstoles. Por último, aborda el objetivo último de su estudio, que es el análisis del mapa del Beato de Osma realizado a finales del siglo XI probablemente en el monasterio de Sahagún. Dando contenido a la relación entre identidades, terrritorios 
y memoria a través del estudio de los mapas que se indica en el título de su trabajo, la autora muestra la importancia de la figura del apóstol Santiago y de Compostela en el mapa, frente a una representación más modesta de Jerusalén y frente también al silenciamiento de Toledo (p. 254).

En definitiva, se trata de un libro variado, con contribuciones diversas, pero que merece la pena leer en conjunto. Con la diversidad mencionada, el coordinador y los autores han sabido encontrar un hilo conductor en la historia del poder, de los poderes, y su proyección espacial y en los textos escritos. Por otro lado, desde una perspectiva más académica que historiográfica, el libro es muestra también de la vitalidad y la madurez de un equipo de investigación de referencia en el panorama actual. Vitalidad y madurez que son ambas necesarias; así, junto a trabajos de historiadores bien conocidos y que cuentan con una muy amplia trayectoria, el lector encontrará también aportaciones de investigadores jóvenes, que muestran el futuro de este equipo y, por extensión, de una línea de investigación ("poderes, espacios y escrituras") que, en renovación continua, como muestra este libro, ha sido y seguirá siendo una seña de identidad de la historiografía medievalista castellana.

\author{
Ignacio ÁLVAREZ BORGE \\ Universidad de la Rioja \\ ignacio.alvarez@unirioja.es
}

